\begin{tabular}{|l|l|}
\hline $\begin{array}{l}\text { 2. To: (Receiving Organization): } \\
\text { Distribution }\end{array}$ & $\begin{array}{l}\text { 3. From: (Originating Organization) } \\
\text { Plutonium Finishing Plant }\end{array}$ \\
\hline $\begin{array}{l}\text { 5. Proj./Prog./Dept./Div.: } \\
\text { PFP Prog. Mgmt. }\end{array}$ & $\begin{array}{l}\text { 6. Design Authority/Design Agent/Cog. Engr.: } \\
\text { J. C. Sinclair I I I }\end{array}$ \\
\hline
\end{tabular}

4. Related EDT No::

626775 thru 626783

7. Purchase Order No.:

$\mathrm{N} / \mathrm{A}$

9. Equip./Component No.

$\mathrm{N} / \mathrm{A}$

10. System/BIdg./Facility:

N/A

12. Major Assm, Dwg. No.:

$N / A$

13. Permit/Permit Application No.:

$\mathrm{N} / \mathrm{A}$

14. Required Response Date:

$N / A$

15.

DATA TRANSMITTED

\begin{tabular}{|l|l|}
\hline $\begin{array}{c}\text { (A) } \\
\text { Item } \\
\text { No. }\end{array}$ & (B) DocumentDrawing No. \\
\hline 1 & HNE-3729 \\
\hline & \\
\hline & \\
\hline & \\
\hline & \\
\hline & \\
\hline
\end{tabular}

16.

\begin{tabular}{|l|l|}
\hline Approval Designator (F) & \\
\hline $\begin{array}{l}\text { E, S, Q, D OR N/A } \\
\text { (See WHC,CM-3-5, } \\
\text { Sec. 12.7) }\end{array}$ & $\begin{array}{l}\text { 1. Approval } \\
\text { 2. Release } \\
\text { 3. Information }\end{array}$ \\
\hline
\end{tabular}

17.

$\begin{array}{lll}\text { (C) Sheet } & \text { (D) Rev. } & \text { (E) Title or Description of Data Transmitted } \\ \text { No. } & \text { (E) }\end{array}$

(F)

(G)

\begin{tabular}{|c|c|}
\hline$(\mathrm{H})$ & $(\mathrm{I})$ \\
\hline $\begin{array}{c}\text { Origi- } \\
\text { nator } \\
\text { Dispo- } \\
\text { stion }\end{array}$ & $\begin{array}{c}\text { Receiv- } \\
\text { er } \\
\text { Dispo- } \\
\text { sition }\end{array}$ \\
\hline 1 & \\
\hline & \\
\hline & \\
\hline
\end{tabular}

KEY

Reason for Transmittal (G)

4. Review
5. Post-Review
6. Dist. (Receipt Acknow. Required)

SIGNATUREIDISTRIBUTION

(See Approval Designator for required signatures)

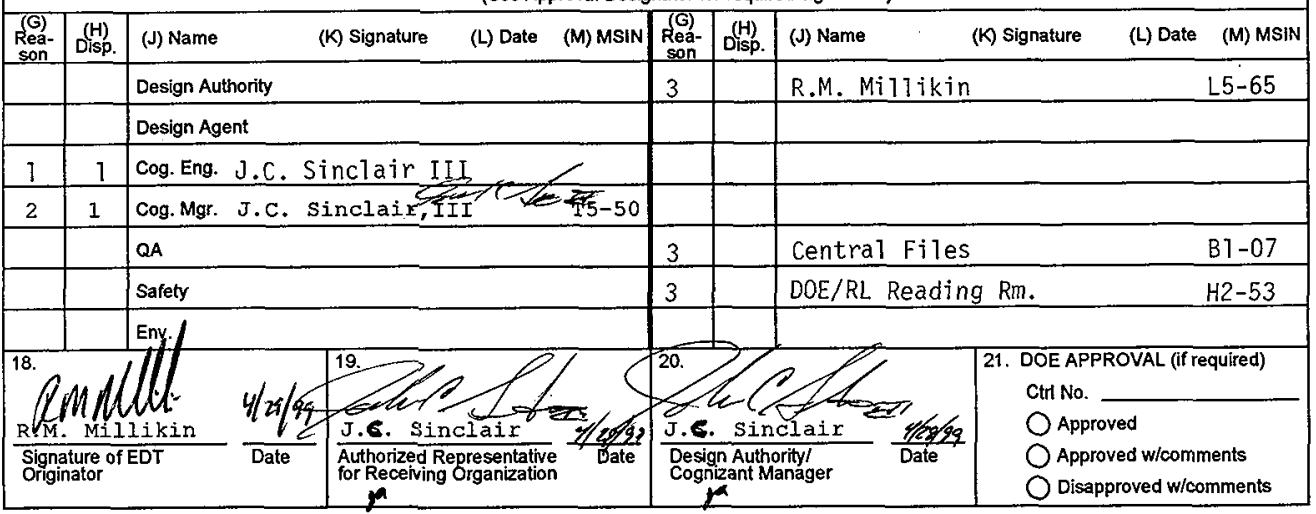




\title{
PFP Functional Development Planning Guide
}

\author{
J. C. Sinclair
}

B\&W Hanford Company

P. 0. Box 1050, Richland, WA 99352

U.S. Department of Energy Contract DE-AC06-96RL13200

$\begin{array}{llll}\text { EDT/ECN: } & 626779 & \text { UC: } 2000 & \\ \text { Org Code: } & 15000 & \text { Charge Code: } 103403 / \text { AROO } & \text { HN990431 } \\ \text { B\&R Code: } & \text { EW04J1050 } & \text { Tota7 Pages: } 7\end{array}$

Key Words: PFP, Functions, Functional Analysis

Abstract: This document includes the planning guide used for the development of the PFP functions and the process used for the functional analysis. The PFP life-cycle project was re-baselined in FY99. The PFP life-cycle baseline is documented in the Integrated Project management Plan for the Plutonium Finishing Plant Stabilization and Deactivation Project, HNF-3617.

TRADEMARK DISCLAIMER. Reference herein to any specific comercial product, process, or service by trade name, trademark, manufacturer, or otherwise, does not necessarily constitute or imply its endorsement, recommendation, or favoring by the United States Government or any agency thereof or its contractors or subcontractors.

Printed in the United States of America. To obtain copies of this document, contact: WHC/BCS Document Control Services, P.O. Box 1970, Mailstop H6-08, Richland WA 99352, Phone (509) 372-2420; Fax (509) 376-4989.
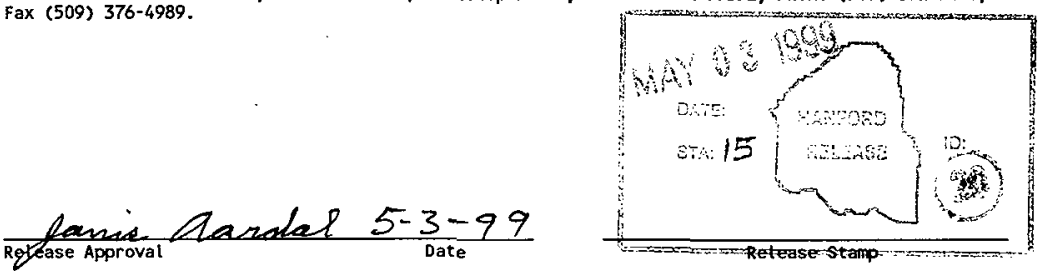

\section{Approved for Public Release}




\section{PFP Functional Development Planning Guide}

HNF-3729, Rev. 0

Prepared by

B\&W Hanford Company and Fluor Daniel Hanford, Inc.

Prepared for

U.S. Department of Energy, Richland Operations Office 
Table of Contents

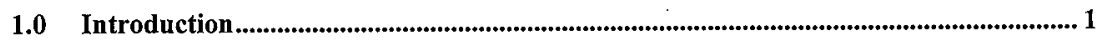

2.0 Statement of Need .................................................................................................................. 1

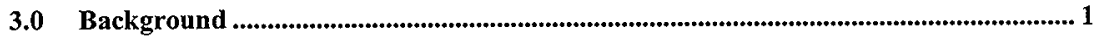

4.0 Definitions............................................................................................................................. 2

5.0 Functional Baseline Development Approach ........................................................................ 3

5.1 Collection and Review of Documentation ......................................................................... 3

5.2 Assembly and Allocation of Functions ..................................................................... 3

5.3 Allocation of Requirements to the Functions................................................................ 3

5.4 Integrated Baseline Development....................................................................................... 3 


\subsection{Introduction}

The PFP Functional Development Planning Guide presents the strategy and process used for the identification, development, and analysis of functions (activities) necessary to satisfy the requirements within the Plutonium Finishing Plant (PFP) integrated project baseline. The functional analysis will provide the basis for the development of a function driven work breakdown structure. Future revisions to this document will include as attachments the results of the PFP Functional Analysis resulting from this approach.

This document is intended be a Project-owned management tool. As such, the guide will periodically require revisions resulting from improvements of the information, processes, and techniques as now described.

\subsection{Statement of Need}

To complete the implementation of the overall Systems Engineering/Project Management approach to the development of the upgraded and accelerated PFP project baseline, a thorough understanding and analysis of functions is required. A complete and approved functional baseline will ensure that system functions (i.e., work breakdown structure) have been considered and will meet the requirements identified by the PFP Requirements Development Process.

\subsection{Background}

The PFP Stabilization and Deactivation Project (hereafter referred to as the Project) is entering the stabilization and deactivation phases of its life cycle. A functional baseline is needed to:

- satisfy the Project's Requirements Baseline

- assist in developing the Project's technical logic

- provide a foundation for the work breakdown structure

- support the development of process flow diagrams

- assist in defining the subproject boundaries and organizations.

A Functional Analysis defines what must be done to satisfy requirements, and therefore accomplish the Project's mission. The activities and products, which result from the Functional Analysis, are the essential building blocks of the Project's Technical Baseline. 


\subsection{Definitions}

The following provides the reader and the reviewer of the planning guides used in the development of the PFP Integrated Project Management Plan with common terms and their definitions:

Activity-Based Cost Estimate - An activity-based cost (ABC) estimate is prepared at the lowest practical level in the work breakdown structure (functional breakdown) where labor, equipment, and material costs can be defined for the activity.

Integrated Baseline - The interrelated aspects of the technical scope, project schedule, and activity-based cost estimate make up the Integrated Baseline. Key elements of the Project's Integrated Baseline will be documented electronically in the Technical Baseline Management System. Key baseline elements, which will be maintained electronically, include work breakdown structure and dictionary (e.g., functions and functional analysis), requirements, issues/assumptions, interfaces, location descriptions, basis of estimate, schedule information, milestones, and requirements closure criteria.

Functional Analysis - The Functional Analysis defines what the system must do (i.e., the activities or "functions") to achieve the overall objectives (mission) and defines the internal and external interactions among the activities. The Functional Analysis is the basis for the Project's technical logic, work breakdown structure, definition of subprojects, the organization structure, the Project's files, process flow diagrams, and definition of the Project's Technical Baseline.

Requirements Analysis - The Requirements Analysis consists of the identification of the applicable requirements. This analysis results in the Project's requirements baseline, which is the foundation for identifying the activities, which will satisfy these requirements (the functional analysis). All requirements must be allocated to the individual functions or elements of the system. Requirements will be maintained in the Technical Baseline Management System, as an integral part of the Project's Technical Baseline.

Systems Engineering/Project Management Modified Approach - The Systems Engineering/Project Management Modified Approach is a focused accelerated effort undertaken to develop the upgraded and accelerated PFP project baseline. The approach uses the fundamental concepts of systems engineering, combined with the rigor of sound project management principles, to come up with a defensible and traceable requirements-based Technical Baseline.

Technical Baseline - The Technical Baseline is the body of technical information associated with the personnel, the processes, and the products required to accomplish the Project's mission. The initial Technical Baseline is a formal description of functions (activities), their sequence and interactions, and the requirements and constraints needed to define the system. The Technical Baseline also provides the basis to develop cost estimates and schedules used for management of work. A Technical Baseline may evolve over the Project's life cycle from a Requirements Baseline, through a Design Baseline, an As-built Baseline, an Operational Baseline, and a Deactivation Baseline. 


\subsection{Functional Baseline Development Approach}

The process described below is used to develop the functional baseline for the upgraded and accelerated PFP project baseline. This approach is derived from the PHMC Systems Engineering Management Plan, HNF-MP-007.

\subsection{Collection and Review of Documentation}

The Functional Analysis approach begins with the collection and review of existing PFP and Hanford Site documentation to identify applicable functions from current planning efforts. Documents are assessed to determine if they are a valid source of functional activities that need to be performed at PFP. Personnel preparing the Functional Analysis are to work closely with members of the PFP Tiger Team B, PFP plant management, and the personnel developing the baseline process logic diagrams, to ensure the Functional Analysis is complete and consistent with these efforts.

\subsection{Assembly and Allocation of Functions}

The functional activities are assembled and allocated down to the lowest practical level in a logical hierarchy. Systems software is used to present the hierarchy in a graphical manner. Once the functions are defined and allocated, detailed descriptions of each function are prepared in a tabular format. For each function, a unique function number, a descriptive function title, a scope of work description, issues, enabling assumptions, alternatives considered, decision points, and interfaces is recorded. As the functions are assembled and defined, they are reviewed and validated by subject matter experts and facility personnel. New functions may be added while others may be consolidated, modified or deleted based on the reviews and the technical basis for the changes. In some cases, these reviews may identify additional issues that must be resolved. An issues management list is established to deal with additional issues. Where necessary, additional enabling assumptions or planned decision points may be necessary to manage the issues in a manner that allows for the Technical Baseline development to proceed.

\subsection{Allocation of Requirements to the Functions}

As the functional activities are assembled and validated, each function is linked to each applicable requirement. When completed, each function or group of functions is linked to all applicable requirements. This is an iterative process and may identify areas where additional functions are needed or where identified functions are not required.

\subsection{Integrated Baseline Development}

The Functional and Requirements Analyses, along with the development of the baseline process flow diagrams, will result in the definition of a functional work breakdown structure, which can be used in the development of the cost and schedule baselines. Function logic is also the formulation for the development of process flow diagrams utilized during design and process control phases of the Project. The tabular information collected during the Requirements Analysis is placed in the technical baseline management system database for future use in the development of basis of estimates. 
This page intentionally left blank. 